\title{
Identify the Source of Resistant Against Collar Rot of Groundnut Caused by Aspergillus niger Van Tiegham
}

\author{
Mahendra Kumar Saran ${ }^{1}$, Dama Ram², J.R. Verma ${ }^{2}$ and Anand Choudhary ${ }^{3}$ \\ ${ }^{1}$ Department of Plant Pathology, CCS Haryana Agricultural University, Hisar, Haryana, India. \\ ${ }^{2}$ Department of Plant Pathology, CoA, Jodhpur, Agriculture University, Jodhpur, Rajasthan, India \\ ${ }^{3}$ Department of Plant Pathology, CoA, Bikaner, Swami Keshwanand Rajasthan Agricultural University, Bikaner, Rajasthan, India \\ "Corresponding author: saranmk862@hau.ac.in (ORCID ID: 0000-0001-6216-894X)
}

Paper No. 942

Received: $16-08-2021$

Revised: 22-11-2021

Accepted: 29-11-2021

\begin{abstract}
Cultivation of resistant varieties seems to be the most economical and sustainable control measure of collar rot disease of groundnut. Twelve groundnut varieties along with one susceptible check were screened against collar rot disease caused by Aspergillus niger under field condition. Among them none of entry was found immune or resistant to collar rot. Three cultivars TG-37A, HNG-69 and GJG-22 were shown 1-10\% disease incidence and considered as moderately resistant. Four cultivars GG-20, GG-7, GL-501 and GJG-9 were shown 11-20\% disease incidence and considered as moderately susceptible. However, TMV-2 was shown $>51 \%$ disease incidence and considered as highly susceptible reaction.

\section{HIGHLIGHTS}

( Growing of resistant variety is the most economical and sustainable control measure of collar rot.

(0 TG-37A, HNG-69 and GJG-22 were considered as moderately resistant to collar rot of groundnut.
\end{abstract}

Keywords: Screening, collar rot, cultivars, Aspergillus niger, PDI

Groundnut (Arachis hypogaea L.) is an important and a member of leguminosae family widely grown food legume and oil seed crops of tropics and sub-tropic regions of the world. It is an important source of oil for majority of human population of world and is a rich source of protein for human and animal consumption. Groundnut kernals contains $48-50 \%$ of edible oil and $26-28 \%$ protein, along with rich dietary fibre, minerals and vitamins (Ntare et al. 2008). Hence, groundnut is popularly known as "poor man's badam". Groundnut cake is also good source of organic manure which contains high nitrogen $(7.0-8.0 \%)$ and other nutrients. It is also used for the feeding of cattle and poultry. Groundnut is one of the most important oilseed kharif crop in India and regarded as "king of oil seed crops" (Reddy 1976). China is the largest producer as well as consumer of groundnut in the world with production of 16.62 million tonnes followed by India (6.70 million tonnes), Nigeria (3.02 million tonnes) and United States (2.57 million tonnes) annually. India rank first in term of area and second in production of groundnut. In India it is grown in the states viz; Gujarat, Andhra Pradesh (Anonymous, 2018-19)

Collar rot caused by A. niger Van Teighem is one of the most important disease of groundnut which is more broad in the kharif than the rabi and summer seasons and causes more harm in sandy loam and medium dark soil. Yearly world yield misfortune due to collar rot is more than 10 per cent (Pande and Rao 2000). Collar rot disease on groundnut seedlings was first revealed by (Jochem 1926) and

How to cite this article: Saran, M.K., Ram, D., Verma, J.R. and Choudhary, A. 2021. Identify the Source of Resistant Against Collar Rot of Groundnut Caused by Aspergillus niger Van Tiegham. Int. J. Ag. Env. Biotech., 14(04): 543-545.

Source of Support: None; Conflict of Interest: None 
in India it was accounted for by (Jain and Nema 1952) as Aspergillus blight. Development of resistant varieties is the most economical and sustainable control measure of collar rot. Hence, the present study was planned to identify resistance sources against collar rot disease in groundnut variety, which could provide a broader genetic base to facilitate the development of resistant cultivars.

\section{MATERIALS AND METHODS}

\section{Cultivars screenings against collar rot of groundnut}

Twelve cultivars of groundnut along with susceptible checks TMV-2 received from Directorate of Groundnut Research (DGR), Junagarh (Gujarat) were screened against collar rot of groundnut to locate the sources of resistance under natural conditions at Instructional Farm, College of Agriculture, Jodhpur, Agricultural University, Jodhpur during kharif season 2019. Observations per cent seed germination and per cent disease incidence were recorded at 60 days after sowing. After estimating disease incidence, the cultivars were categorized into different groups based on disease reaction viz., immune, resistant, moderately resistant, moderately susceptible, susceptible, highly susceptible as per (Mayee and Datar, 1986).

Per cent disease intensity was calculated by using the formula mentioned under here.

$$
\begin{gathered}
\text { PDI }=\frac{\text { Sum of individual disease ratings }}{\text { Total No. of plant assessed }} \times \\
\frac{100}{\text { Maximum diseases rating }}
\end{gathered}
$$

\section{The following Groundnut cultivars were selected for the present study}

1. Spanish bunch with short duration: GG-7, Pratap Mungphalli-1, TMV-2 and JL 501.

2. Spanish bunch with medium duration: TG37A and GJG-9 (J-69).

3. Virginia bunch with short duration: GG-20.

4. Virginia bunch with medium duration: GJG-22 (JSSP-36), Girnar-2, HNG-69, HNG123 and Phaulemorna (KDG-123).

\begin{tabular}{|c|c|c|}
\hline Disease rating & $\begin{array}{l}\text { Disease intensity } \\
(\%)\end{array}$ & Disease reaction \\
\hline 0 & No disease & Immune \\
\hline 1 & $<1 \%$ mortality & Resistant \\
\hline 3 & $1-10 \%$ mortality & $\begin{array}{l}\text { Moderately } \\
\text { resistant }\end{array}$ \\
\hline 5 & $11-20 \%$ mortality & $\begin{array}{l}\text { Moderately } \\
\text { Susceptible }\end{array}$ \\
\hline 7 & $21-50 \%$ mortality & Susceptible \\
\hline 9 & $>51 \%$ mortality & Highly susceptible \\
\hline
\end{tabular}

Table 1: Reaction of genotypes against collar rot diseases

\section{RESULTS AND DISCUSSION}

\section{Screening of available cultivars against collar rot}

Twelve groundnut cultivars along with one susceptible check TMV-2 were screened against $A$. niger under field conditions. None of entry was found immune or resistant to collar rot. Three cultivars TG-37A, HNG-69 and GJG-22 were shown 1-10\% disease incidence and considered as moderately resistant. Four cultivars GG-20, GG-7, GL-501 and GJG-9 were shown 11-20 \% disease incidence and considered as moderately susceptible. Four cultivars Girnar-2, HNG-123, KDG-123, Pratapmungphali-1 were shown $21-50 \%$ disease incidence and considered as susceptible and TMV-2 was shown $>51 \%$ disease incidence and considered as highly susceptible. However, the differences among these cultivars based on the per cent collar rot incidence were not significant (Table 2).

Similar results were also observed by Kumari et al. (2016) screened fourteen varieties of groundnut against collar rot, five observed moderately resistance, six found susceptible and three were highly susceptible. Divya Rani et al. (2018) Screened 40 advanced breeding lines along with susceptible checks JL-24, J-11 and TMV-2, against collar rot ( $A$. niger) under green house conditions. The result revealed that among 40 lines the 10 lines found resistant and shown less than $15 \%$ disease incidence. These resistant genotypes include ICGV 00202, ICGV 00211, ICGV 86590, ICGV 91114, ICGV 05155, ICGV 00350, ICGV 93261, ICGV 92195, ICGV 92035 and ICR 48. 
Table 2: Response of different groundnut cultivars against collar rot

\begin{tabular}{llll}
\hline Groups & $\begin{array}{l}\text { Disease } \\
\text { incidence }\end{array}$ & Genotype reaction & Details of cultivars \\
\hline Group I & 0 & Immune & - \\
Group II & $<1 \%$ & Resistant & - \\
Group III & $1-10 \%$ & Moderately resistant & TG-37A, HNG-69, GJG-22 \\
Group IV & $11-20 \%$ & Moderately Susceptible & GG-20, GG-7, GL-501, GJG-9 \\
Group V & $21-50 \%$ & Susceptible & Girnar-2, HNG-123, KDG-123, Pratapmungphali-1 \\
Group VI & $>51 \%$ & Highly susceptible & TMV-2 \\
\hline
\end{tabular}

\section{CONCLUSION}

Twelve groundnut cultivars along with one susceptible check were screened under field condition against collar rot among these three cultivars viz., TG-37A, HNG-69 and GJG-22 showed moderately resistant reactions, whereas four cultivars viz., GG-20, GG-7, GL-501 and GJG9 showed moderately susceptible reactions, four cultivars showed susceptible reaction and one cultivars showed highly susceptible reaction. None of the cultivars showed immune and resistant reaction under field condition.

\section{REFERENCES}

Anonymous, 2018-19. Directorate of Economics and Statistics, Department of Agricultural, Cooperation and Welfare.

Divya Rani, V., Sudini, H., Narayan Reddy, P., Vijay Krishna Kumar, K. and Uma Devi, G. 2018. Resistance Screening of Groundnut Advanced Breeding Lines against Collar Rot and Stem Rot Pathogens. Int. J. Pure Applied Biosci., 6(1): 467-474.
Jain, A.C. and Nema, K.G. 1952. Aspergillus blight of groundnut seedlings. Sci. Culture, 17: 348-349.

Jochem, S.C.J. 1926. Aspergillus niger on groundnut. Indisch Culturen (Teysmannia), 11: 325-326.

Kumari, M., Singh, M., Godika, S., Choudhary, S. and Sharma, J. 2016. Effect of different fungicides, plant extracts on incidence and varietal screening against collar rot of groundnut (Arachis hypogaea L.) caused by Aspergillus niger van Tiegham. Int. Quarterly J. Life Sci., 11(4): 2835-2839.

Mayee, C.D. and Datar, V.V. 1986. Diseases of groundnut in the tropics. Review Trop. Plant Pathol., 5: 85-118.

Ntare, B.R., Diallo, A.T., Ndjeunga, J. and Waliyar, F. 2008. Groundnut Seed Production Manual. Patancheru, 502324. Andhra Pradesh, India. (ICRISAT). 20.

Pande, S. and Rao, J.N. 2000. Changing scenario of groundnut diseases in Andhra Pradesh, Karnataka and Tamil Nadu states of India. Int. Arachis Newsletter, 20: 42-44.

Reddy, M.V. 1976. Crop management of groundnut, irrigated and dry crop. Paper read at $9^{\text {th }}$ annual workshop-cumseminar on an India Coordinated Research Project on Oilseed Crops held at Nagpur on 5-9th April, 1976. 
